Stevens, Martin. "The Narrator of The Wife's Lament." Neuphilologische Mitteilungen 69 (1968): 72-90.

Walker-Pelkey, Faye. "Frige hweet ic hatte': 'The Wife's Lament' as Riddle." Papers on Language and Literature 28 (1992): 242-66.

\title{
The Collational Formula of Caxton's Second Edition of the Canterbury Tales
}

Often, the copy of Caxton's second edition of the Canterbury TalesCx2-held at the St. John's College's Library, Oxford, has been described as perfect (De Ricci; Mosser "Witness Descriptions," Wife and General Prologue) and, naturally, this copy is often used as a reference for the ideal collational formula of $\mathrm{Cx} 2$.

In A Census of Caxtons, De Ricci had proposed the following collational formula: "312 leaves ( 1 is blank): $a-1^{8} v^{6} a a-h h^{8} \mathrm{ii}^{6} \mathrm{~A}-\mathrm{K}^{8} \mathrm{~L}^{4}$ " (27), with a final gathering of four leaves and a total of 312 leaves for the complete book. Later Paul Needham corrected De Ricci's formula as follows: " $F^{\circ}$ a$t^{8} v^{6}$ aa-hh ${ }^{8}$ ii $^{6} A-K^{8} L^{6} ; 312$ leaves" (Needham 87), where he corrects the last gathering from four leaves, as proposed by De Ricci, to six. Dan Mosser gives the following collation for $\mathrm{Cx} 2$ : " 312 leaves ( $\mathrm{I}$ is blank): $\mathrm{a}-\mathrm{t}^{8} \mathrm{v}^{\mathrm{6}}$ aa$\mathrm{hh}^{8} \mathrm{ii}^{6} \mathrm{~A}-\mathrm{K}^{8} \mathrm{~L}^{6}$ (following Needham's revision of previous collations, which posit a gathering of four)."

All the previous collational formulae refer to an ideal copy of the book, which by definition should be complete. It would appear that after Needham's revision of the number of folios in the last quire, he did not change the total number of leaves for the book. The result of this is that, on one hand, De Ricci's collational formula is consistent in the sense that the number of leaves and the formula correspond with one another. On the other hand, Needham presents a collational formula that adds up to 314 leaves by asserting that the final quire has six leaves, not four; at the same time, he states that the book has a total of 312 leaves. It is likely that Mosser copied the formula from Needham without realizing the inconsistency in the numbers given. The main problem posited by Needham's updated collational formula is that if it were correct, the book should have 314 folios. If the number of leaves were correct, that is, if the book had indeed 312 folios, his collational formula would have two extra leaves and would not show the correct quiring. In fact, the correct ideal collational formula for $\mathrm{Cx} 2$ should be:

fol: : a-t ${ }^{8} \mathrm{v}^{6}$ ata-hh ${ }^{8} \mathrm{ij}^{6} \mathrm{~A}-\mathrm{K}^{8} \mathrm{~L}^{6}, 314$ leaves.

The St. John's copy has 312 leaves, and it is cvident that the first and last 
leaves (al, [L6]) have been cut out from the Canterbury Tales. ${ }^{2}$ The quires can be easily checked and show that the Needham collational formula for an ideal copy of $\mathrm{Cx} 2$ is correct, which confirms that the book originally had 314 leaves. When Mosser comes to the description of the St. John's copy his collational formula reads "perfect.". However, Mosser is not the only one who uses this term when referring to this particular book. In the facsimile we also find it when Bennet states: "Only thirteen copies of the book are cxtant, and all are imperfect save for that in the Library of St. John's College." (Probably, both Mosser and Bennet have taken the term and their idea of the completeness of the St. John's copy from De Ricei, who also describes the book as perfect (De Ricci 28). However, a collation of the St. John's copy will show that it has 312 pages and so must be defective, that is, imperfect.

De Ricci also describes leaves that are now missing in Troilus and Criseyde, but considering his mistake in the description of the Canterbury Tales one might feel inclined to doubt the correctness of this one. If the St. John's copy of the Tales had been complete in 1909, not only would De Ricci's collational formula be wrong but the actual number of leaves found in the St. John's copy would have been different; that is, he would have stated that there were 314 leaves and would have provided a different collation formula. At this point, the correct collational formula for the St. John's copy of $\mathrm{C} x 2$ is:

fol: $\mathrm{a}^{(8-1)} \mathrm{b}-\mathrm{t}^{8} \mathrm{v}^{6}$ aa-hh ${ }^{8} \mathrm{ii}^{6} \mathrm{~A}-\mathrm{K}^{8} \mathrm{~L}^{(6-1)}, 312$ leaves (f. 312 blank).

The St. John's College copy of $\mathrm{C} \times 2$ was the surviving copy believed to be perfect. This copy, however, lacks both al and $[\mathrm{L} 6],{ }^{4}$ which means that at this time there is no known complete copy of $\mathrm{Cx} 2$.

BARBARA BORDALEJO

De Montfort University, United Kingdom

\section{NOTES}

1. After submitting my dissertation, it was brought to my attention that Lotte Hellinga has independently reached the same conclusions I reached while analyz: ing the St. John's College copy of Cx2. Her research will be published in Catalogut of Books printed in the XVth Century now in the British Museum [Library|, vols. $1-10$ and 12 (London, 1908-1962) vol. 11 fortheoming.

2. There is another leaf missing from Troilus and Criseyde.

3. This term cannot be found in any standard manual of bibliography. Cf. Bowers, McKerrow, and Gaskell.

4. The St John's College copy seems to be textually complete. Both Caxton's preface and the text of the Canterbury Tales are present.

\section{WORKS CITED}

Bennet, J. A. W. "Note." The Canterbury Tales. Cambridge: Commarket Reprints in association with Magdalene College, 1972. n. pag. 
Bowers, Fredson. Principles of Bibliographical Description. Princeton: Princeton UP, 1949.

De Ricci, Seymour. A Census of Caxtons. Illustrated monographs (Bibliographical Soc.); no. 15. London: Bibliographical Soc., 1909

Gaskell, Philip. A New Introduction to Bibliography. New York: Oxford UP, 1972.

McKerrow, Ronald Brunless. An Introduction to Bibliography for Literary Students. Oxford: Clarendon, 1928.

Mosser, Daniel W. "Witness Descriptions." The General Prologue on CD-ROM. Ed. Elizabeth Solopova. CD-ROM. Cambridge: Cambridge UP, 2000.

"Witness Descriptions." The Wife of Bath's Prologue on CD-ROM. Ed. Peter M. W. Robinson. CD-ROM. Cambridge: Cambridge UP, 1996.

Needham, Paul. The Printer \& the Pardoner. Washington, DC: Lib. of Congress, 1986.

\section{Alchemical Fiction and Political Transformation: The History of the Golden Eagle}

In 1672 a pseudonymous author, Philaquila, published The History of the Golden Eagle, a short work of prose fiction that was republished in 1677 and again in 1700 . For all practical purposes, this prose romance has been neglected by scholars. The modern editor of this work sees it as a Märchen, or fairy tale, typical of some of the popular fiction of the time, ' while Margarct Spufford labels it a nonchivalric romance and a "threadbare absurdity" (236-37). J. Paul Hunter perceives this unusual romance as one of the popular, early prose narratives that focuses on the marvelous, the unusual, and the magical (30)-32, 195-224). ${ }^{2}$ In this essay, I want to situate this neglected romance narrative within its social and political contexts to demonstrate how even popular fiction generates political meanings by appropriating other discourses. In this case, I want to argue that the Golden Eagle is a scrious political allegory that employs a sophisticated alchemical narrative to deliver its political message. ${ }^{3}$ Specifically, the author employs the romance genre to treat the civil war and subsequent Restoration to create a political allegory designed to support Charles II's return to the throne and the reassertion of monarchical absolutism.

Recently, Gerald MacLean has argued that the Restoration created a "cultural crisis of textual representation" in which the Stuart monarchy "mobilized many different psychic, political, and poetical registers seeking to reinscribe monarchic idcology in ways that would make the king's return seem acceptable and unquestionable" (256-57). Following Maclean, Jonathan Sawday argues that we need to understand how all "symbolic registers" were "stage managed in order to produce the illusion that the trans- 